\title{
The Role of Trade Costs in the Russian-Paraguayan Trade Relations
}

\author{
Valeriia S. Ryzhkova* \\ Alexandra G. Koval **
}

\begin{abstract}
The changed geopolitical situation and deterioration of Russia-West relations has induced the expansion of trade and economic cooperation between Russia and Latin American countries. Currently, Paraguay is explicitly showing its readiness to strengthen recently built trade relations with Russia. In order to fuel their increased mutual interest, it is crucial to struggle with impediments that hinder the trade between them. The export potential assessments demonstrate that Russia and Paraguay indeed have potential to intensify bilateral trade, even though the opportunities for export diversification are quite limited. The authors conduct a survey to identify the major trade costs and their role in the development of the Russian-Paraguayan trade relations. The survey findings reveal that transportation and logistics costs significantly impede the exports of both countries as well as information-related obstacles represent the top concern for Russian export companies, while non-tariff measures, language and cultural barriers are relevant for Paraguayan firms. In order to intensify the Russian-Paraguayan commercial relations, the policy makers could deal with these barriers via a higher exchange of market information through different institutional channels.
\end{abstract}

Keywords: Trade costs, non-tariff barriers, export potential, Russia, Paraguay.

\section{Resumen}

El cambio en la situación geopolítica y el deterioro de las relaciones entre Rusia y Occidente han inducido la expansión de la cooperación comercial y económica entre Rusia y los países latinoamericanos. Actualmente, Paraguay está mostrando explícitamente su disposición a fortalecer las relaciones comerciales establecidas recientemente con Rusia. Para exacerbar su creciente interés mutuo, es crucial luchar contra los impedimentos que dificultan el comercio entre estos países. Las evaluaciones del potencial de exportación demuestran que, de hecho, Rusia y Paraguay tienen potencial para intensificar el comercio bilateral, aunque las oportunidades para la diversificación de las exportaciones son bastante limitadas. Los autores realizan una encuesta para identificar los principales costos comerciales y su rol en el desarrollo de las relaciones comerciales ruso-paraguayas. Los resultados de la encuesta revelan que los costos de transporte y logística impiden de manera significativa las exportaciones de ambos países, como también los obstáculos relacionados con la información que representan la principal preocupación de las empresas exportadoras rusas, mientras que las medidas no arancelarias, las barreras lingüísticas y culturales son relevantes para las empresas paraguayas. Para intensificar las relaciones comerciales rusoparaguayas, los formuladores de políticas podrían enfrentar estas barreras a través de un mayor intercambio de información de mercado en diferentes canales institucionales.

Palabras claves: Costos comerciales, barreras no arancelarias, potencial de exportación, Rusia, Paraguay.

\footnotetext{
* MA in Economics, Saint Petersburg State University. Email: valeriya.nikiforova@bk.ru. Received: September, 18th 2018; accepted: November 14th 2018.

** Ph. D. in Economics, Associate Professor, Saint Petersburg State University. Email: a.koval@spbu.ru
} 
Valeriia S. Ryzhkova, Alexandra G. Koval

The Role of Trade Costs in the Russian-Paraguayan Trade Relations

\section{Introduction}

Under the recent changes in the geopolitical situation, the Russian Federation has been transforming its economic policy and searching new trade partners. The confrontation with the Western countries has provoked the expansion of Russia's trade and economic cooperation with Latin America and the Caribbean (LAC), which refused to support anti-Russian sanctions (Jeifets, 2015).

The majority of studies mainly focus on the political factor of the Russian-Latin American relations (Blank\& Kim 2015; Cruz, 2015; Pavlova, 2017) and just some of them examine the nature of economic cooperation between Russia and LAC (Davydov, 2016; Koval, 2017). Trade remains the main channel for the cooperation, and trade relations are explored in research about Russia's trade policy in LAC either in general or towards main regional trade partners in particular (Lopez Arevalo, 2018; Paniev, 2013). However, all these studies primarily include the analysis of trade dynamics and structure. There is an evident gap in barriers research, which prevent them from the development of Russia-LAC trade. In other words, the question is what policy makers could do in order to intensify not only political but also trade contacts.

The theory of trade costs could help to explain the obstacles in trade cooperation between countries and find a number of cost-effective policies to reduce trade costs and thus enhance trade ties. However, they all require a case-by-case approach. Mechanical replication of "best practices" does not result in effective facilitation of trade across borders, which requires policy makers to take into account countries-specific circumstances (Moïsé \& Le Bris, 2013). This research will be the first investigation of trade costs in trade between Russia and LAC.

The paper will focus on the case of Russian-Paraguayan trade due to the following reasons. First, Paraguay is one of the top-10 Latin American trade partners for the Russian Federation. However, the Russian export has grown very slowly during the past decade. Second, currently Russia and Paraguay are explicitly showing their readiness to strengthen bilateral economic relations (Tavdumadze, 2017). The establishment of the Paraguayan-Russian Chamber for the Development of Trade, Industrial and Cultural relations in Asunción in December 2017; visits of Paraguayan and Russian delegations as well as extensive dialogues at the economic forums confirm countries' willingness to cooperate. Moreover, after the official visit of the Paraguayan president to Russia in June 2018, it has been announced the initiation of negotiations on the agreement of strategic alliance between two countries (RIA Novosti, 2018). Nevertheless, bilateral trade between Russia and Paraguay remains negligible and extremely imbalanced. Finally, despite the recent intensification of political and institutional contacts between these two countries, there are a very few studies on their cooperation(Cabral López, 2018). Thus, the investigation will cover this gap as well as introduce a relatively new approach in the analysis of Russian-Latin American cooperation.

The aim of the paper is to identify the major trade costs and their role in the development of the RussianParaguayan trade relations. Prior to clarify trade costs that are most likely to prevent the two countries from trading more, the authors also prove that Russia and Paraguay indeed have the gap between what they could export and what they actually export. It thus adds value to the current research on costs in trade between particular countries. Furthermore, this research produces a deeper understanding of trade relationship between Russia and Paraguay that so far have received a poor attention. In addition, this 
research meets an urgent need to reveal the role of different impediments to the Russian-Paraguayan trade so that policy makers know what to target as a priority. The decrease of trade costs in RussiaParaguay case can also cause a virtuous circle along the trade chain and have a positive impact on RussiaLAC trade relations in general.

The rest of this paper is organised as follows. The second section reviews the literature relevant to the concept of trade costs and their influence on trade flows. Then, it presents the relevant database for the research and explains the methodological background for a business survey. In the fourth section, the estimation of the export potential in the Russian-Paraguayan trade clarifies the list of exporters for the trade costs survey. The fifth section provides the findings on major costs hindering the development of trade between Russia and Paraguay. Finally, the paper concludes with possible policy implications and perspectives for further research.

\section{Literature review}

Trade costs belong to one of the key factors influencing companies' decision to become exporters (Melitz, 2003). Bernard, Jensen \& Schott (2006) and Muendler (2004) show that trade costs reduction increases a number of exporters not engaged in international trade before, encourages targeting new markets and revitalises previously established trade relations.

The generally accepted understanding of "trade costs" as all possible costs incurred to export or import products, provides a margin to decide what obstacles should be considered as giving rise to trade costs and what shouldn't. Hummels (1999) divides trade costs into three components, namely explicitly measured costs (freight, tariffs), costs captured by proxy variables (distance, common language, and common border) and unmeasured costs. Kaukin \& Idrisov (2013) agree that while some costs emerging during the export-import process can certainly be observed, others remain unobservable. Kaukin, Pavlov \& Filicheva (2015) quantitatively prove that institutional and infrastructure components have the influence, comparable in scale with the impact of direct transportation costs.

In 2004, Anderson \& van Wincoop published a frequently cited article where they attempt to determine the location of costs emergence. The authors split up all trade costs into two large categories: international trade costs and local distribution costs (wholesale and retail). The former component comprises the costs associated with national borders (policy-related costs (tariffs and NTMs), information costs, costs associated with the use of different currencies, language related costs and contract enforcement costs) and costs related to geographic frictions such as distance. Noteworthy, this decomposition might mislead with regard to policy-related costs, which are seemingly captured only by tariffs and NTBs.

Shepherd (OECD/WTO, 2015) solves this problem explicitly distinguishing between locational factors and policy-related factors that cause trade costs. The former include geographically and historically predetermined factors. The latter come in three types: at-the-border, between-the-borders and behindthe-border measures. Moïsé \& Le Bris (2013) develop a more elaborated picture of distributing the costs with regard to the border. They state that numerous hurdles that emerge before the goods reach the border, directly at the border and behind it lead to policy-related costs mainly because of trade finance inaccessibility, poor infrastructure, lengthy customs procedures, tariffs, burdensome NTMs, transparency 
Valeriia S. Ryzhkova, Alexandra G. Koval

The Role of Trade Costs in the Russian-Paraguayan Trade Relations

and distribution problems. Transportation and logistics costs are viewed as transversal to the whole trade chain.

The modified version of gravity model (Novy, 2013), which was theoretically justified by all basic international trade theories and which is commonly used to link trade costs and trade flows, enabled the creation of the comprehensive Trade Costs database. According to this database, the countries of Europe and Central Asia experience the highest costs in trade with the countries of Latin America and the Caribbean, to which Russia and Paraguay belong respectively (UNESCAP/World Bank, n.d.). It means that trade costs could cause minor trade flows between investigated states. One might argue that the low volumes of Russian-Paraguayan trade reflect the maximum capacity due to countries' comparative advatages. However, some experts highlight that Russian trade with LAC doesn't reach its potential (Yakovlev, 2017).

The recent studies have confirmed that trade costs represent a significant barrier in the development of trade especially for emerging economies and developing countries (Diakantoni et al., 2017; Martí\&Puertas, 2017). Some scholars have specifically investigated the role of trade costs for the Russian traders (Eliseeva, 2014; Sopilko et al., 2017) as well as for Paraguayan ones (Almeida et al., 2018). Nevertheless, there is no research on trade costs in the Russian-Paraguayan trade. The paper hopefully opens appropriate discussions and reveal the main challenges and prospects for future studies in this field.

\section{Methodology}

The research is based on both primary and secondary data. For revealing the export potential in the Russian-Paraguayan trade, the authors analyse the estimations of the International Trade Centre's (ITC) database. The results of ITC data investigation provide the sectors both in Russia and Paraguay, where the countries have the highest potential to trade, and the companies from these particular sectors become a main source for collecting the primary data by means of a business survey.

ITC has elaborated the export potential assessment methodology based on a combination of different supply, demand and easiness to trade factors (Decreux \& Spies, 2016). Supply capacities of an exporting country are assessed through a number of indicators, such as revealed comparative advantage (RCA), growth of RCA, export-import ratio and global tariff disadvantage. Country has a revealed advantage if the share of a product in its total exports exceeds the share of this product in world exports (RCA $\geq 1$ ). Otherwise, the country has a relative disadvantage $(\mathrm{RCA}<1)$. The growth factor is calculated as the ratio of RCAs during two periods of three years $(2012$ - 2014 and 2015 - 2017). This ratio is then used to project RCA and predict competitive export products in the future.

Demand side is analysed through indicators such as share in market demand, growth in this share, tariff advantage in the target market and a distance factor. The third component in computation of potential export value is easiness to trade. It captures the effects of having previously established commercial links, sharing the common border, the same language and culture or having complementary export and import baskets.

ITC uses some measures ensuring that the reports of unreliable data do not distort the results. First, the averages of five-year period (2013-2017) are used. Second, in order to ensure that only unceasingly 
supplied and demanded goods are suggested as having export potential, ITC considers products which were imported in all five years and exported at least in the last three years under consideration. Third, both direct and mirror values are used to estimate "true" export and import flows.

Eventually, potential export value is obtained. It indicates the level at which a certain product can be exported given current supply capacity of an exporter, the demand in the target market and market access conditions. When potential exports exceed actual exports, this reveals the untapped potential, which might arise due to, for instance, decrease of trade costs. According to ITC's general assessment, Russia could increase its exports to Paraguay around fourfold and Paraguay could almost double its exports to Russia.

The detailed analysis of ITC database could reveal the sectors, where both countries have the highest export potential. The deeper investigation of companies' attitudes from these sectors to barriers in bilateral trade could disclose the nature and main characteristics of existing trade costs. That is why the research follows with the survey in order to reveal the opinions of Russian and Paraguayan companies on the major trade costs they face or expect to face when trading with each other.

Business survey could help to identify the main impediments in the development of Russia-Paraguay trade potential as private exporters and importers are the first agents to be aware of the constrains in the trade flows. If exporting companies know trade barriers, they will attempt to overcome or bypass them (Hausmann et al., 2008): for instance, they can engage in informal trading to avoid the cumbersome administrative procedures. Likewise, the companies can decide not to export to a certain market if they see trade costs as unacceptable. With this regard, Moïsé and Le Bris (2013) highlight the extreme usefulness of business surveys in assessing what stakeholders view as the most hindering factors.

So far, the analysis of ITC database represents the Russian and Paraguayan exporting products, which have an untapped potential of at least US $\$ 200,000$, and companies exporting these products introduce the representative sample for the survey. Searching by the specified products' HS codes in the database of Russian exporters ${ }^{1}$, we identified 155 companies currently exporting the products with an untapped potential to Paraguay. In order to compile a list of Paraguayan producers of goods with export opportunities to Russia, we used the Guide on Paraguay's exports ${ }^{2}$ and found out 141 export companies.

Note that the authors relied exclusively on the results of quantitative estimations of trade potential between the two countries and did not take into consideration some qualitative information, such as governments' claims; there are some reasons for that. First and foremost, we pursued the goal of maintaining research consistency. We acknowledge that the potential of some sectors might have been underestimated by the quantitative estimations. However, on the grounds of the governments' statements, we still could not reveal particular promising products and thus were unable to specify the companies to survey. In addition, the governments' views might not coincide with businesses' capacities, which we believe to be essential for trade development.

\footnotetext{
${ }^{1}$ http://www.ved.gov.ru/eng/companies/exporters/

${ }^{2}$ http://www.guiaparaguayexporta.com.py/
} 
In order to collect the data, questionnaires were sent. We approached Russian exporters in Russian and Paraguayan exporters in Spanish. The questionnaire concerned trade between Russia and Paraguay; specifically, the importance of trade costs in general and their certain types in particular. It also asked the exporters to elaborate on specific impediments they encounter or expect to encounter when trading with each other. In addition, respondents were asked to identify the location of major trade costs' concentration.

The inferences of Shepherd (OECD/WTO, 2015) and Moïsé and Le Bris (2013) on barriers generating trade costs along the international trade chains formed the basis for compiling the questionnaire. It aimed at collecting the views on the following sources of trade costs. First, the ones arising naturally due to cultural or language differences. Second, arising before reaching the border due to domestic standards, scarcity of trade finance, poor transport infrastructure, etc. Third, trade costs arising at the border due to tariffs, non-tariff measures, customs procedures, corruption, etc. Fourth, the ones arising beyond the border due to lack of transparency, foreign regulations, distribution services, etc. Finally, transport and logistics costs.

Our survey was web based. We sent out the questionnaires via e-mail providing two possibilities for completion, first, using the Google Form, and second, filling the questionnaire attached to the e-mail and sending it back. The e-mails with request to complete the survey were sent twice. Eventually, we received 9 responses from Russian companies and 10 responses from Paraguayan firms. According to Molchanov (2018), in case of electronic surveys, the response rate does not exceed 1\%; our result is consistent with this estimation. Valuable comments of companies' representatives were also analysed.

It must be stated that, from the Russian side, only one out of nine companies that completed the questionnaire, currently exports to Paraguay. At the same time, 6 out of 8 companies that are not currently exporting to Paraguay, consider it as a prospective trading partner. In the Paraguayan case, three companies currently export to Russia, six consider Russia as a prospective trade partner and the last one is not focused on the Russian market.

Our research has two major limitations. First, we focused on the export side and did not consider the major trade costs from the importers' perspective, which surely matters for the overall trade picture. Second, given the number of questionnaire responses we managed to receive, the findings of our survey cannot be generalised, but they give the background for several conclusions and further research.

\section{Russia-Paraguay Trade Potential}

In 2017, Russia-Paraguay merchandise trade accounted for US\$ 645.4 million, US\$ 625.3 million of which were the exports of Paraguayan products to Russia. Graph 1 demonstrates that since 2007, bilateral trade has regularly increased and reached a peak of US\$1,187.9 million in 2014. After that, trade flows have been gradually declining mainly due to the decreased price of soybeans and the restrictions imposed by the Russian authorities upon Paraguayan meat. For instance, on May 11th 2018, Russia introduced a temporary restriction on the supply of meat products from one Paraguayan company because of its suspicion of re-exports of prohibited beef from Brazil. This case presents the evidence of trade costs in bilateral trade. 
Graph 1: Trade flows between Russia and Paraguay in $2003-2017$

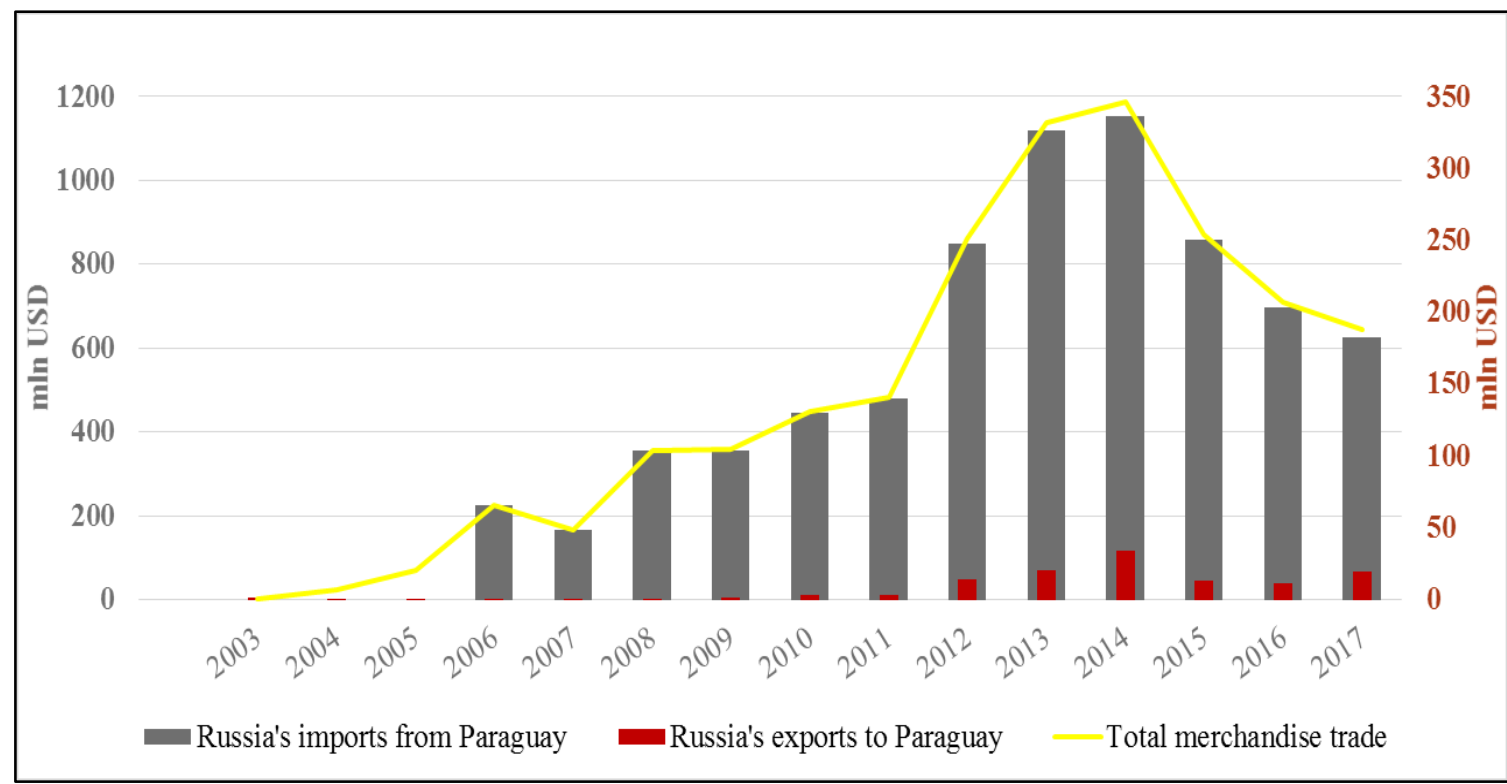

Source: Federal Customs Service of Russia (2018).

Commodity structure of trade between the countries reveals the lack of diversification. Russia primarily exports fertilisers and aluminium. Paraguay, in turn, supplies mainly soya beans and meat (Graph 2). The share of technological and machinery products in Russian-Paraguayan trade is very low.

\section{Graph 2: Commodity structure of the Russian - Paraguayan trade in 2017}

\section{Russia's exports to Paraguay}

$1 \% \quad 5 \%$

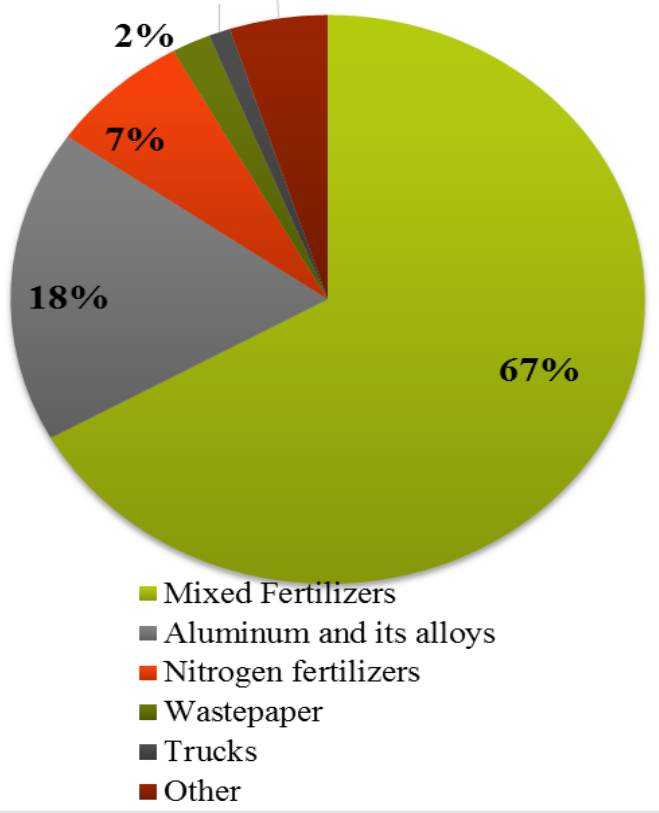

\section{Russia's imports from Paraguay}

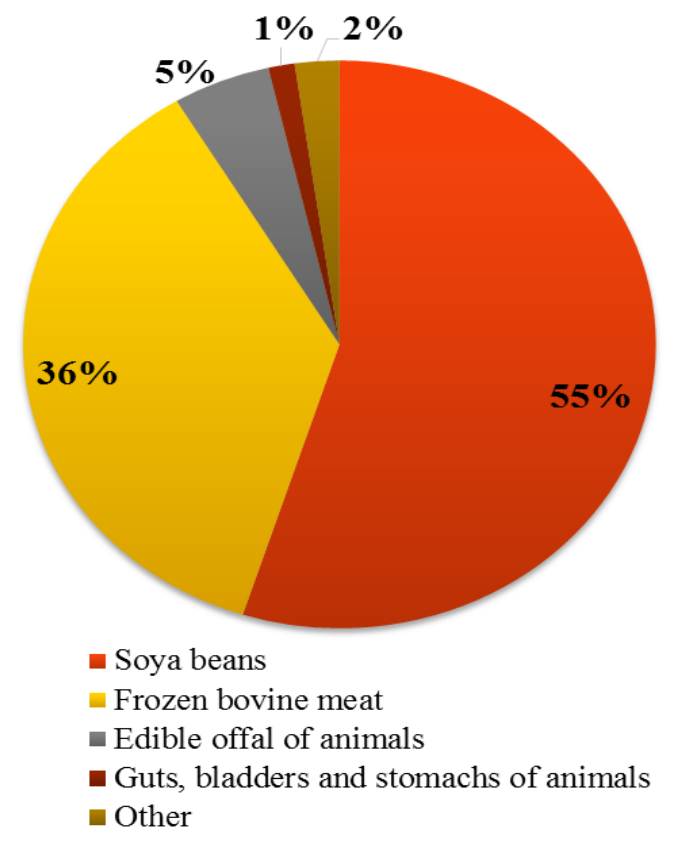

Source: Federal Customs Service of Russia. 
Valeriia S. Ryzhkova, Alexandra G. Koval

The Role of Trade Costs in the Russian-Paraguayan Trade Relations

Despite the low export from Russia to Paraguay, according ITC estimations, Russia has the potential to increase its export supply. Graph 3 (as well as Graph 4) demonstrates products with a total export potential of at least US $\$ 200,000$. Fertilisers and chemicals represent about $80 \%$ of total unrealised potential in Russia's export to Paraguay. Steel products, aluminium alloys and rubber tires represent also the group of products with a certain potential. In consistency with the enquiries of the ParaguayanRussian Chamber for the Development of Trade, Industrial and Cultural Relations, more foodstuff and beverages (such as beer and chocolate) could be also exported from Russia to Paraguay. Being a part of the Initiative on the integration of regional infrastructure in South America, Paraguay has a number of its own large-scale projects (e.g. building a new airport, regional and national roads, railway electrical system, bridges on the rivers Paraguay and Paraná, etc.). Given these projects, Russia could supply some construction materials, such as Portland cement, cement clinkers and glass articles. With regard to technological products, ITC spots some unexploited potential of television apparatus (the leading Paraguay's imported good among manufactures), washing machines, electric conductors, vehicles for the transport of persons and some vessels, totally augmenting to US\$1,648 million of additional exports.

\section{Graph 3: Russia's products with export potential in Paraguay's market}

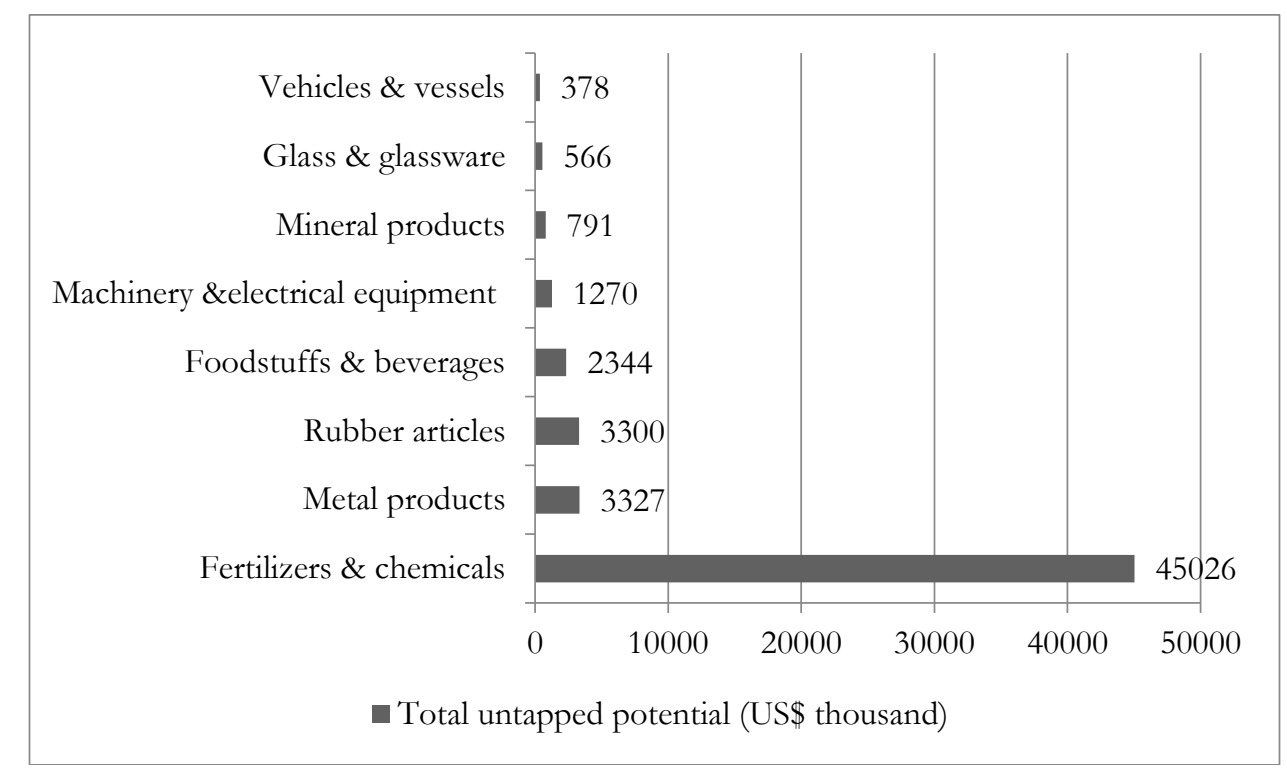

Source: Compiled by authors on the basis of ITC's Export Potential Map data.

The Russian Export Centre (REC), a state-owned export-promoting agency, quantitatively assessing the foreign markets attractiveness for the Russian exports of non-primary non-energy goods, including technological products, confirms relative unattractiveness of Paraguayan market for Russia's tech exports. According to REC's Ranking 2018, Paraguay comes in 131st place out of 135 possible (REC, n.d.). However, the results of ITC and REC's assessments largely diverge from the Russian government's claims. While visiting Paraguay in 2017, the Russian delegation clearly stated a preferable list of goods for its exports, which includes only technological products, such as agricultural machinery, equipment for the development of transport, water supply and sanitation infrastructure, and aircrafts (Ministry of Industry and Trade, 2017).

The Russian intention to intensify exports of high value added products to Paraguay is in line with the government's general idea to support the non-commodity exports (Medvedev, 2016). Nonetheless, it 
remains unclear whether the Russia's desire coincides with its readiness to do so, i.e. with the capacities of Russian businesses, as well as with the capacity of Paraguay's market. Meanwhile, the Paraguayan market is often viewed as insufficiently capacious for Russian machinery and technical products (Korchagin, 2007). Nevertheless, there was no analysis whether the elimination of trade costs could encourage trade development between countries. REC (2016) has done a research on barriers encountered by Russian exporters while conducting and expanding export operations; however, this study reveals general barriers and does not allow for the peculiarities in Russia's trade with different countries.

\section{Graph 4: Paraguay's products with export potential in Russia's market}

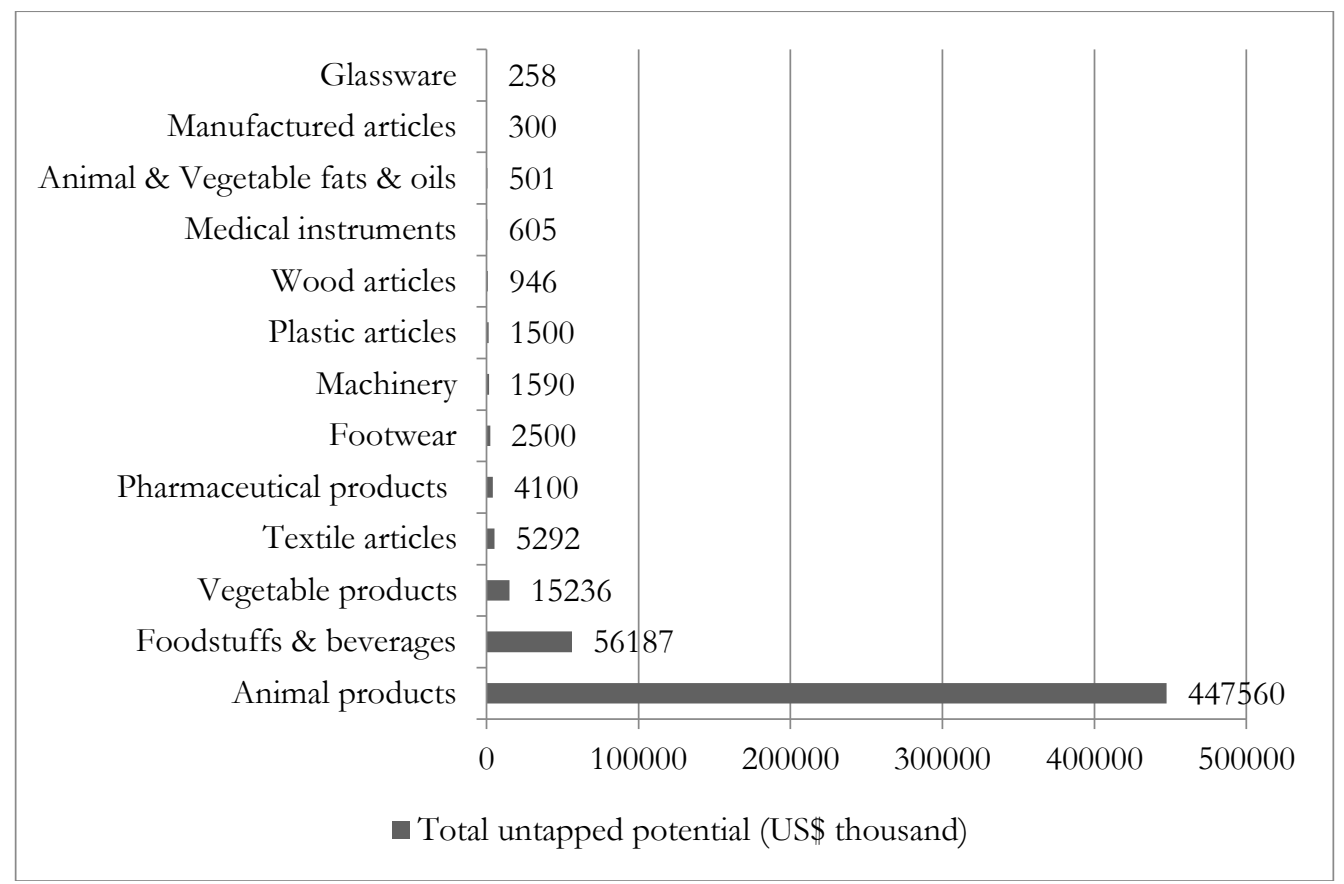

Source: Compiled by authors on the basis of ITC's Export Potential Map data.

Likewise Russia, Paraguay's by far biggest export opportunities concentrate in one sector, namely in the animal-based one (Graph 4); it represents a hefty $83 \%$ of the total export potential. Even though other sectors hold significantly less promise, they still present the opportunities for growth and diversification of Paraguay's exports to Russia. Various vegetable products, apart from soya beans, could add over US\$ 15 million in export revenues. Paraguay also possesses some opportunities for diversification of its exports to Russia into manufactured products. The leading sector in this domain is textile industry. Moreover, uppers of footwear are estimated to bring additional US $\$ 2.5$ million. Russia is also an attractive market for some plastic, wood and glass articles. Export potential assessment suggests a couple of medicaments for retail sale and syringes for medical sciences as feasible options for export growth. As regards tech products, Paraguay keeps some potential, even though not huge (US\$ 1.6 million), in exporting dairy machinery and wiring sets for vehicles.

By and large, the findings of ITC's assessment coincide with the results of the Paraguayan export promoting agency REDIEX's analysis of the potential of international markets for Paraguayan products (REDIEX, 2015). The Paraguayan-Russian Chamber for the Development of Trade, Industrial and 
Cultural relations' export offer confirms our findings on export potential in the realm of agricultural products, although it does not contain any manufactured products. It might be due to the Chamber's membership, mostly represented by agricultural producers, on whose behalf the organisation operates. However, again the question is how to explore this export potential. The studies confirm that Paraguayan exporters face certain trade barriers on foreign markets (ITC, 2013). The nature of these barriers in particular within Russian-Paraguayan trade could be revealed by a trade costs survey of companies exporting products with a higher potential (Graphs 3 and 4).

\section{Trade costs survey findings}

In general, trade costs are an important issue for Russian companies when choosing an export market. $78 \%$ of companies consider trade costs important or very important when making a decision regarding a destination market for their products. The rest $22 \%$ see other issues as more important; such as geopolitical landscape or market capacity, according to the respondents' comments on this question. For instance, a foreign economic activity manager of the Penza confectionary factory has argued that the main reason for not entering the Paraguayan market was its small size. According to Baldwin and Harrigan (2011), smaller market size along with increasing distance between the countries indeed magnify the odds to face zero bilateral trade flows.

Russian companies' representatives consider all the sources of costs in trade with Paraguay reviewed in our survey as important, although to varying degrees. Graph 5 displays the hurdles in order of frequency when reporting their importance. There is no consensus on the most significant impediment to trade with Paraguay. We asked the companies' representatives to rank the three most important obstacles from the list below. The opinions differed widely. As a result, no single hurdle was ranked as the most burdensome by the majority of answerers. 
Graph 5: Most frequently encountered costs in trade with Paraguay from the perspectives of Russian exporters

\begin{tabular}{|r|c|}
\hline The share of respondents who assessed the importance of trade costs \\
determinants by 4 and 5 on a 5-point scale
\end{tabular}

Source: Compiled from questionnaire data.

Information collected through the questionnaire provides some clarifications regarding the essence and components of different sources of trade costs. We start with information-related barriers. What kind of information is not available to Russian exporters? Inability to identify sales prospects discourages Russian companies to enter Paraguay's market the most with a hefty $78 \%$ of respondents sharing this view (Graph 6). One more problem lies in finding potential trading partners; one of the reasons for that, mentioned by the General Director of the National Committee for the Assistance to the Economic Cooperation with Latin American countries, is non-participation or an inadequate participation of Russian businesses in the regional fairs and exhibitions, such as NAVEGISTIC in Paraguay, LAAD in Brazil, FIDAE in Chile, etc. (Mashkova, 2018). A third of respondents indicated the lack of market research of Paraguay's industries and products. Neither the regulatory information from the Russian or Paraguayan side, nor the customs requirements represent the major concern for Russian export companies. 
Valeriia S. Ryzhkova, Alexandra G. Koval

The Role of Trade Costs in the Russian-Paraguayan Trade Relations

\section{Graph 6: The most important information-related barriers in Russia's export to Paraguay}

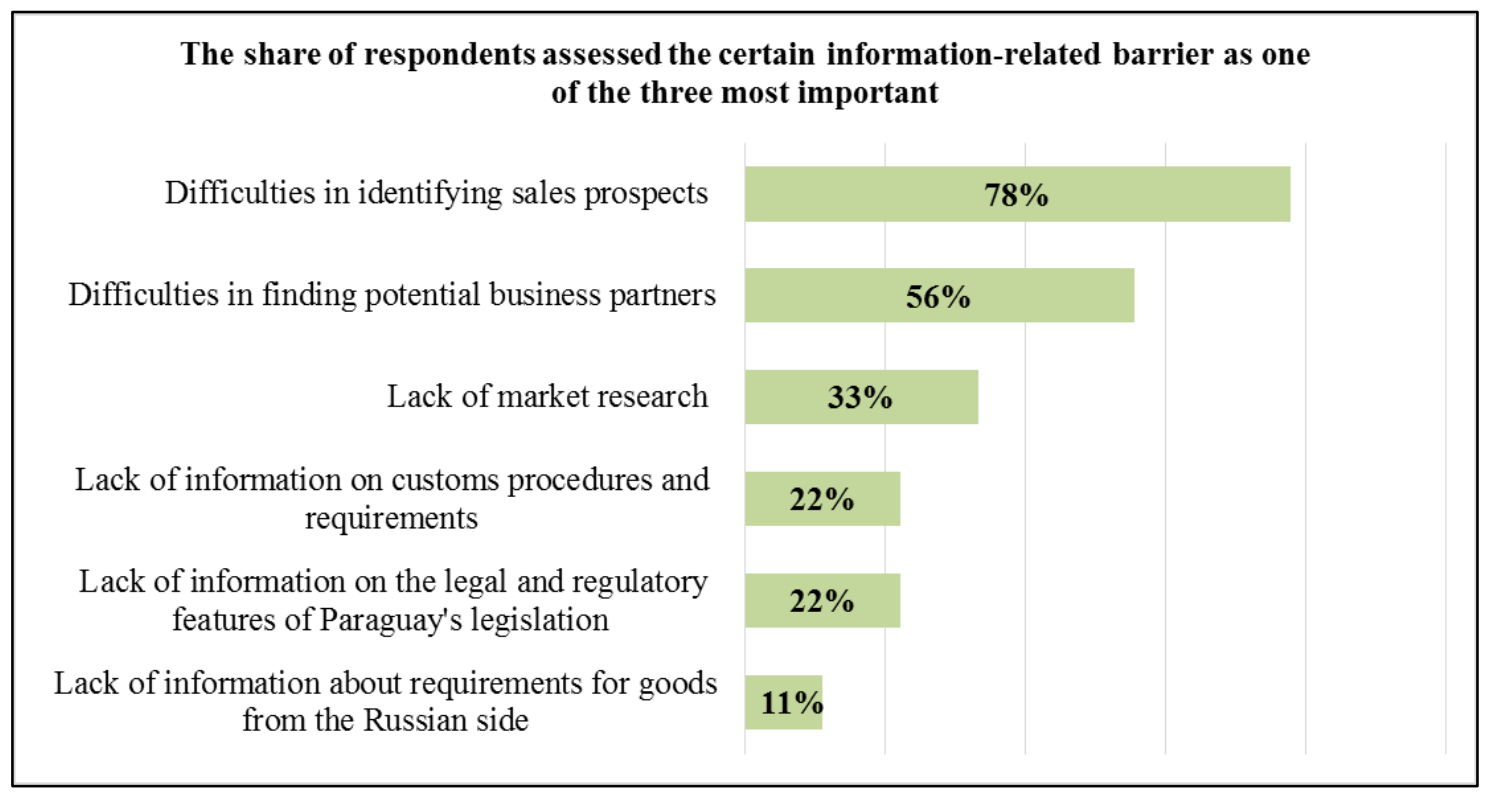

Source: Compiled from questionnaire data.

A low access to information might be the reason for having a room for guesswork with relation to the level of trade costs. Quite often we observed the divergence of opinions between the representatives of companies currently dealing with Paraguay and the exporters not targeting this market. Wrong perception of trade costs, i.e. their overestimation, can significantly discourage prospective exporters to enter the Paraguayan market.

The transportation barrier is quite a predictable problem that inhibits the development of trade between Russia and Latin American countries in general, and Paraguay in particular. It mainly implies high freight rates and complicated and expensive logistics, equally indicated by $78 \%$ of respondents. Another difficulty stated by $44 \%$ of surveyed is the quality of transport infrastructure in Paraguay or in transit countries. The fact that Paraguay is a landlocked country considerably complicates transport situation. However, the country has developed the Paraguay-Paraná Waterway Modernisation Program, which might bring positive changes in this domain. Yet no one indicated the quality of infrastructure in Russia as a problem. Neither container issue was identified as important, with only one company surveyed expecting the difficulties in filling containers.

Regarding distribution barriers, the vast majority of companies (89\%) have identified difficulties in finding distribution agents in Paraguay's market. In addition, the problem of finding a distributor that would unite the markets of most countries of the LAC region was also mentioned. Such a distributor might be in need if Paraguay's market is considered insufficiently capacious for a certain product and, for this reason, the large regional market is seen desirable to be targeted. Noteworthy, the difficulties in finding a distributor is definitely a distribution-related barrier, but can also be considered as an information-related hurdle as major problems arise from the lack of data on the distributors themselves and on their trustworthiness. A third of respondents also noted the importance of restrictions on intermediaries applied by Paraguay's government and concentration of retailers in the market as barriers 
to trade. No problems with reputation of Russian products or restrictions on post-sales services have been identified.

As for language and cultural barriers, $44 \%$ of respondents agreed that the inability to use English in communication considerably complicates the negotiation process. Representatives of companies that currently conduct export to this region confirmed the necessity to conduct a dialogue in the language of Latin American clients, which is Spanish or Guarani in case of Paraguay. Related to the difficulty described above, the problem of translation services emerges, as reported by $33 \%$ of surveyed. Russian companies also highlighted that they have trouble when finding employees who would be well qualified in Spanish land at the same time would understand the scope of business, i.e. professionals in economics, law, medical science, engineering, etc. A third of Russian exporters were also concern with such a cultural feature as preference of domestically produced goods. Only one respondent singled out the problem of providing onsite services in Paraguay.

Among the finance-related issues, problems caused by fluctuating exchange rates noticeably predominate from the Russian exporters' point of view (67\%). The importance of other difficulties related to the access to trade finance and handling financial instruments as well as to the lack of public export financing programs is belittled against the background of the highlighted dominant obstacle. Noteworthy, at the present time, this problem is typical for Russian export companies regardless the direction of their exports and thus cannot be seen as a specific impediment to trade with Paraguay.

At-the-border barriers, while not being the key factor limiting export from Russia to Paraguay, can significantly slow down and complicate the export process, increasing its cost and distracting entrepreneurs from the production cycle. For $67 \%$ of Russian respondents, the major concern presents the number of documents needed for passing the customs (Graph 7). However, some respondents mentioned that the process of handling the documents has become noticeably easier and quicker due to implementation of the electronic system of documents processing at customs. In addition, recently established REC as a "single window" for exporters might improve the situation in the nearest future. However, according to the Trade across Borders ranking by the World Bank (World Bank, 2018), time required for border compliance while exporting to Paraguay (120 hours) is almost twice as high as exporting to Russia (66 hours). Meanwhile, time required for document compliance in export deliveries to Russia and Paraguay is almost the same: about 24-25 hours.

Moreover, 44\% highlighted the problem of exchange control procedure and of the overall complexity of customs administration. Such difficulties considerably increase the delivery time and may cause clearance delays, indicated by $33 \%$ of Russian respondents. Tariff rates, non-tariff barriers (NTBs, or equivalently, NTMs - non-tariff measures) and corruption are not seen as significantly hindering the Russian exports to Paraguay. 
Valeriia S. Ryzhkova, Alexandra G. Koval

The Role of Trade Costs in the Russian-Paraguayan Trade Relations

\section{Graph 7: The most important at-the-border barriers in Russia's export to Paraguay}

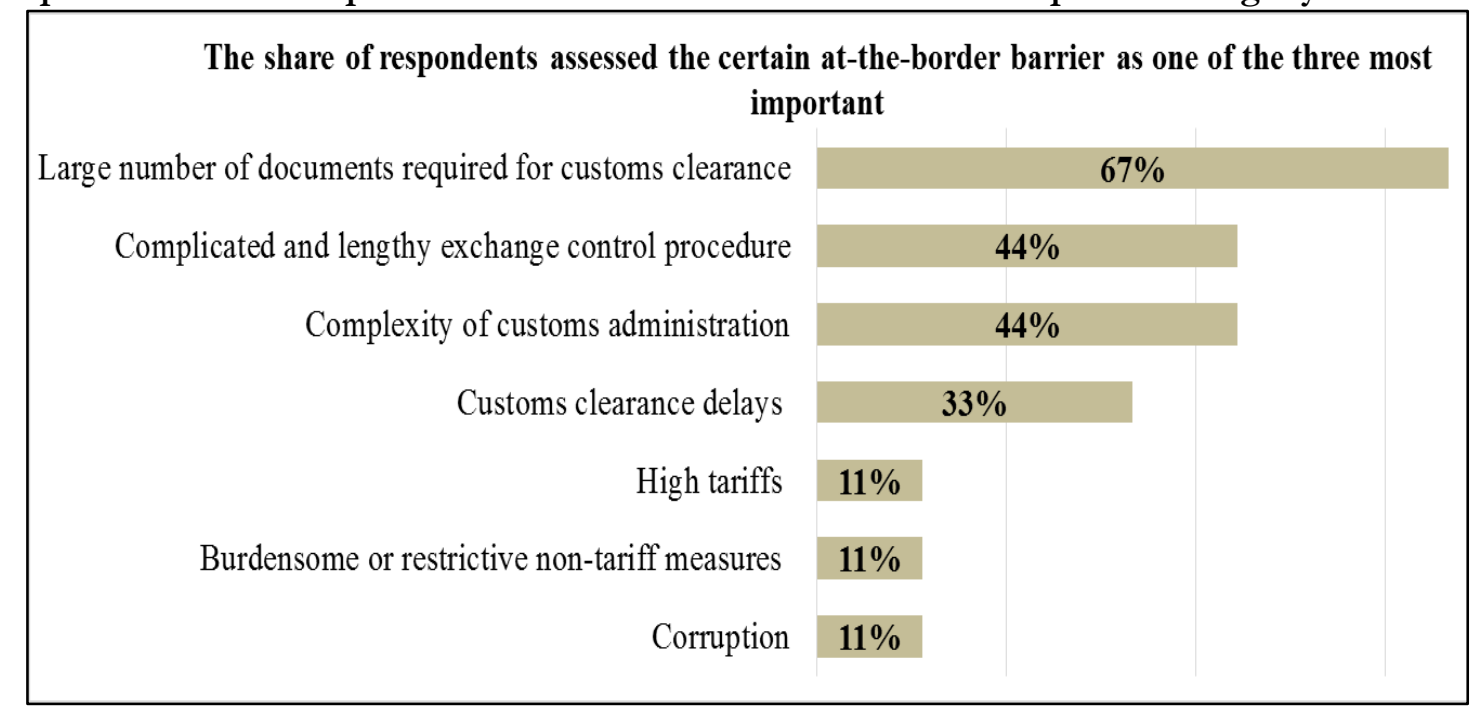

Source: Compiled from questionnaire data.

We also asked the companies to select the major administrative and non-tariff barriers to be faced in Russia and Paraguay. Even though the answer to the previous question has revealed the relative insignificance of impediments of that kind, we still present the results of our analysis in order to gain the full picture of factors hindering trade between the countries. The majority of respondents $(67 \%)$ agreed on the discouraging effect of processes to obtain permits from various organisations, such as the Federal Service for Technical and Export Control, different phytosanitary services, etc. Over 50\% highlighted such an obstacle as the imperfections in tax administration. Indeed, due to the flaws in tax legislation, companies often cannot receive the benefits guaranteed by law (Analytical Center \& REC, 2016). Export charges, quantitative restrictions and price control were viewed less crucial and were accordingly indicated less frequently by $33 \%, 11 \%$ and $0 \%$ of respondents respectively.

It is worth mentioning that Latin American countries may require the documents that Russian authorities simply do not release. Several companies participating in the Conference: "Export Day: How to export and do business with the countries of Latin America" (Saint Petersburg, April 18, 2018) reported this problem. The export director of Baltika Breweries operating in the LAC region confirmed this problem and mentioned that, it took them a year to obtain all the necessary documents to start exporting to Argentina (Gladkih, 2018). In the specially organized interview, one Baltika's representative responsible for entering Paraguay's market highlighted that to enter Paraguay it took them even more, a year and a half.

The problem of the lack of trade intermediaries figured prominently in the overall obstacles to be faced once entered Paraguay. All other measures applied by the Paraguayan government, be it licenses and quotas or compulsory use of national services, lose their importance against the background of the absence of adequate systems aiming at promoting Russian products in Paraguay's market. However, this impediment is certainly not only destination country's fault. Such a response of Russian companies' representatives reflects the absence of the Trade Mission, as well as of trade house of the Russian Federation in Paraguay, which could partially solve this problem. 
Furthermore, we asked the surveyed to determine the location of the highest costs in trade with Paraguay (Graph 8). The opinions divided, although the view of transportation and logistics costs as the most burdensome clearly prevailed (56\%). Transport and logistics company Airtranss participating in the Saint Petersburg Chamber of Commerce and Industry conference "Export Day: How to export and do business with the countries of Latin America" (April 18, 2018) confirmed the expensiveness and lengthiness of the transportation process to the region in general and Paraguay in particular.

Despite the fact that customs procedures were not identified as the most important obstacles hindering the exporting to Paraguay, the costs generated by these procedures were indicated as the highest by $22 \%$ of the answers. There seems to be a contradiction, yet we believe there is not. At-the-border costs can indeed be cumbersome and induce large costs; however, they are typical for the companies engaged in exporting activities and thus do not present a specific concern with regard to Paraguay. Therefore, being onerous, they can hamper the exports in general but may not serve a particular barrier to trade with Paraguay. Other $11 \%$ chose Russia as an origin of the highest trade costs, while the remaining $11 \%$ selected Paraguay. These findings make us believe that the situation in trade between Russia and Paraguay can change for the better if Russian and Paraguayan policy makers take appropriate measures, including those stipulated in the Trade Facilitation Agreement. The overall downward trend in transportation costs (Bernard, Jensen \& Schott, 2006; Hummels, 1999; WTO, 2008) may contribute to this positive change.

\section{Graph 8: The location of the highest costs in Russia's export to Paraguay}

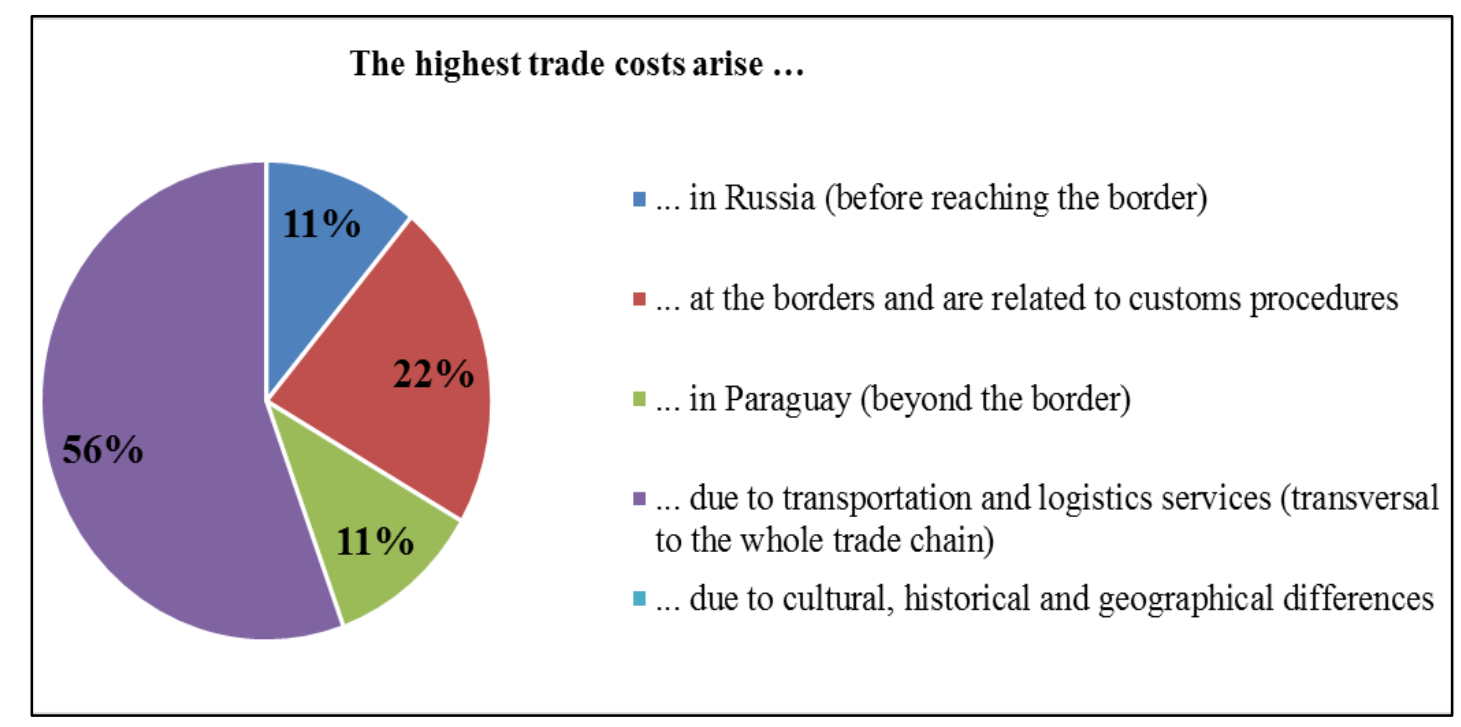

Source: Compiled from questionnaire data.

The question of distinguishing between the general hurdles to export and specific impediments to trade with Paraguay deserves a special attention. We should admit that some problems, especially those arising on the Russian side, are likely to concern all Russian export companies regardless the direction of their exports. In this case, they rather present general barriers to conducting and expanding export activities, but not particular challenges in their relation with Paraguay.

Comparing with the findings of the survey on obstacles encountered by Russian exporters in general (Analytical Center \& REC, 2016), we can conclude that all the most important and the most frequently reported impediments (by over $50 \%$ of respondents), namely difficulties in identifying sales prospects 
and in finding business partners and distributors, expensive freight and complicated logistics are specific to trade with Paraguay. Although the first two difficulties mentioned can be also assigned to the generally encountered ones, we believe that a number of circumstances make the Paraguayan case special in this domain and let us consider these problems as particular to trade with Paraguay. These circumstances include the absence of an adequate information exchange system between the countries as well as the absence of trade houses, insufficient mutual participation of exporters from both countries in exhibitions, fairs and conferences. Among other less important and less frequently indicated barriers, difficulties in using English as a means for negotiation are also specific when doing business with Paraguay. At the same time, fluctuating exchange rates, a large number of documents required for customs clearance, difficulties in tax administration and in obtaining permits are typical for Russian exporters and thus do not determine the trade relations with Paraguay.

Another interesting generalisation issue arises, specifically whether the impediments determined as specific to Paraguay are likely to be faced in case of trading with other Latin American countries. In terms of transportation and logistics costs as well as problems using English for negotiations, the answer is rather yes. However, the fact that Paraguay does not have access to the sea complicates the situation. In terms of information-related barriers, we suppose to face more problems when entering Paraguay's market than targeting countries in Latin America that relatively long ago established commercial links with Russia, such as Brazil, Argentina, Cuba, Mexico, Venezuela and Chile, and thus have better information exchange and a stronger institutional framework for the development of trade relations.

Trade costs do also hamper Paraguayan companies to develop trade relations with Russia. In general, they consider trade costs as a truly important determinant when choosing a destination market for their goods. All the firms surveyed through the questionnaire shared this point of view. Paraguay's trade is highly geographically concentrated on the markets of its neighbouring countries, which in addition, together with Paraguay participate in a number of trade agreements leading to costs reduction (WTO Secretariat, 2017). It is thus likely that costs in trade with Russia would be higher than average for Paraguay's exporters, as indicated by the majority of respondents (80\%). From this, we can conclude that high trade costs may be the most important reason for disregarding Russia's market.

Overall, Paraguayan exporters attach great importance to the impediments that generate costs in trade with Russia. As shown in Graph 9, a hefty 90\% of respondents indicated insufficient access to information and burdensome customs procedures as a stumbling block to export to Russia. Interestingly, while the former impediment is also the most frequently encountered among Russian companies, the latter is one of the least reported by them $(22 \%)$. The only problem highlighted by a smaller number of respondents from Paraguay, than from Russia, is the lack of trained personnel, $20 \%$ against $44 \%$. Noteworthy, none of the three current exporters to Russia has acknowledged the significance of transparency issues, distribution services and the lack of specialised stuff. All three ranked them as moderately important. This fact, as in the Russian case, makes us think that it might take place a divergence in expectations of Paraguayan companies regarding the costs in trade with Russia from the current state of affairs. This divergence, magnified by inaccessibility of information, may considerably hamper the progress in the Paraguayan- Russian trade relations. 


\section{Graph 9: Most frequently encountered costs in trade with Russia (opinion of Paraguayan exporters)}

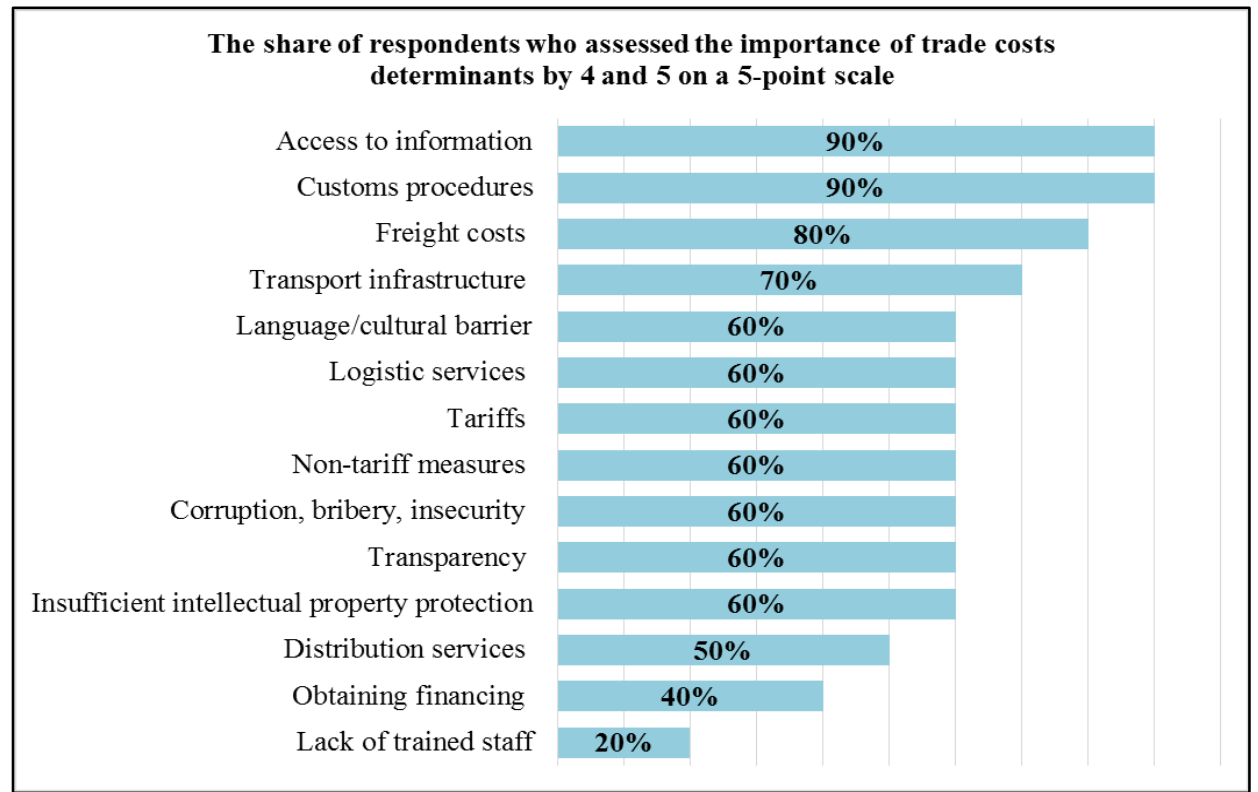

Source: Compiled from questionnaire data

Unlike Russian exporters, Paraguayan export companies came to some consensus regarding the question of the most important impediments to trade with Russia. Freight costs represent the top concern as indicated by $50 \%$ of the respondents. The second largest challenge, reported by $40 \%$ of the companies, is customs procedures. Language- and culture-related barriers and NTBs share the third place of the most significant obstacles with $30 \%$ of total responses.

High freight rates together with complicated and expensive infrastructure indeed represent the primary problems for exporting to Russia within the transportation issue, as indicated by $80 \%$ and $60 \%$ of Paraguayan respondents respectively. The view of Paraguayan exporters replicates the position of Russian export companies regarding these two barriers. Interestingly, Paraguayan companies see more problems in Russian transport infrastructure than in their own or in the one of transit countries. The opinion of Russian respondents is reverse; it makes us think that companies adapt to the conditions in their own countries and once adapted, do not consider them extremely troublesome anymore. Container issues are also of minor concern for Paraguayan companies as for the Russian ones.

The second most serious issue for Paraguayan exporters on their way to Russia is different at-the-border barriers (Graph 10). Such barriers are prominently lead by the onerous NTMs. Large number of documents for customs clearance as well as the overall complexity of passing the border present the problems number two $(50 \%)$ and three $(40 \%)$ respectively. According to the OECD Trade Facilitation Indicators Database (OECD, 2017), Russia matches the average performance of upper middle income countries in all areas aiming to reduce trade costs, except a number and complexity of documentation. The results of our survey indicate that customs procedures in Paraguay are more burdensome and lengthy than in Russia and indeed may present a serious obstacle to trade. Tariffs, corruption, delays and exchange control procedures were seen less important impediments by Paraguayan exporters in comparison with NTBs and burdensome customs procedures. 
Valeriia S. Ryzhkova, Alexandra G. Koval

The Role of Trade Costs in the Russian-Paraguayan Trade Relations

Graph 10: The most important at-the-border barriers in trade with Russia

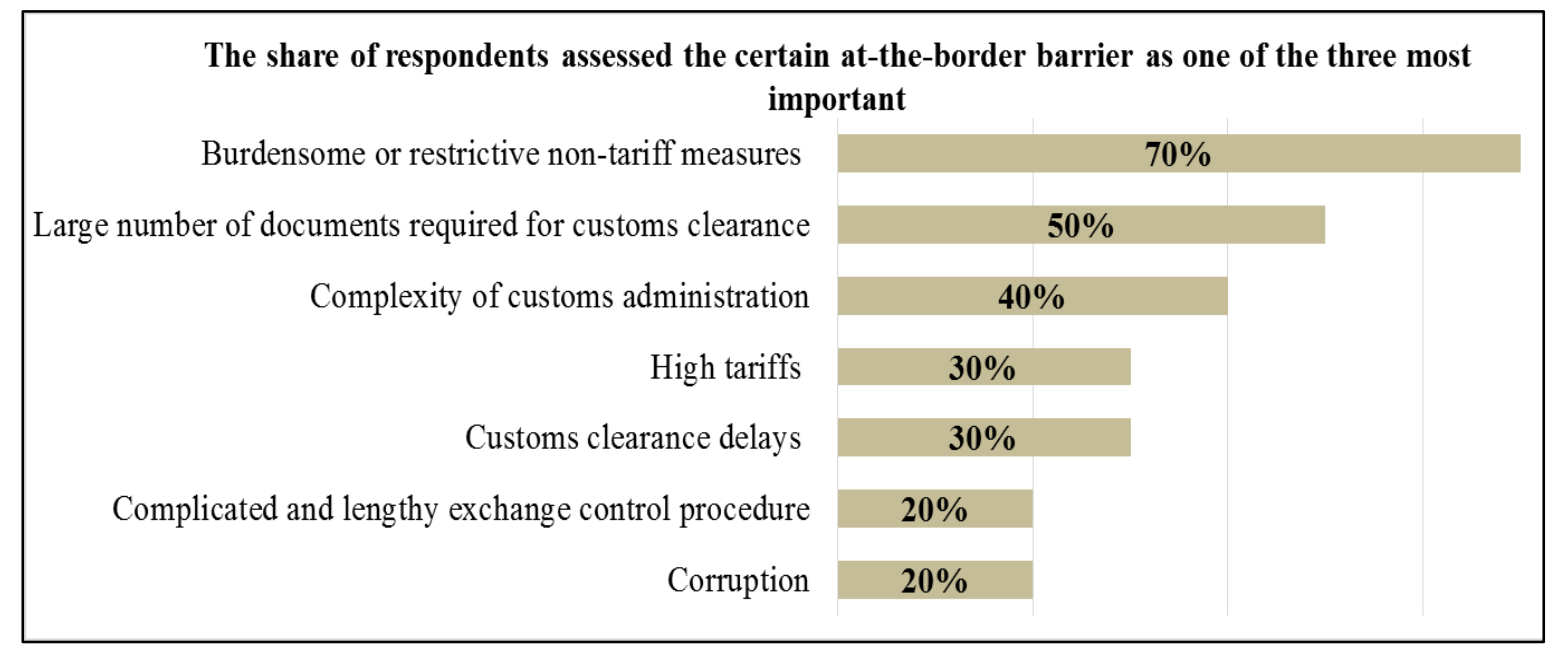

Source: Compiled from questionnaire data

In general, different administrative and non-tariff barriers applied by the Paraguayan government seem to heavily discourage the overall companies' export activities and consequentially hinder the exporting to Russia. According to the results of the ITC's analysis, Paraguay leads the ranking of NTM incidence in Latin America; it has the largest share of export companies affected by various NTBs, $62 \%$ against, for example, $56 \%$ in Uruguay or with $42 \%$ in Peru (ITC, 2013). A hefty $70 \%$ of our respondents are influenced by quantitative restrictions. ITC's investigation found out that $66 \%$ of exports of agricultural products, which are the main Paraguay's export goods, are subject to restrictive measures (ITC, 2013). Complicated tax administration and permits obtainment also prevent Paraguayan companies from trading more as indicated by $50 \%$ and $40 \%$ respectively. Export price controls, not reported by Russian companies, affect $40 \%$ of answered Paraguayan exporters. However, only one out of ten Paraguayan representatives mentioned the presence of export taxes and charges, while among Russian companies three respondents out of nine pointed out to this impediment.

In addition to restrictive steps undertaken by the Paraguayan government, export companies face or expect to be heavily challenged by sanitary and phytosanitary measures (SPS) applied by the Russian government; in fact, $70 \%$ of respondents see them as a major NTB to enter the Russian market. However, we should keep in mind that this impressive number rather stems from the fact that all Paraguayan exports to Russia are represented by agricultural products that are inescapably subject to SPS. Although such measures may be onerous for Paraguayan exporters, they aim at ensuring safety for Russian consumers. Further research on how burdensome SPS imposed by Russia in comparison with other countries of Paraguay's exports is needed in order to make a conclusion on the hindering character of these measures. The Global Trade Alert Database (2018) also provides the information that Russia has applied several harmful measures, which negatively affected trade with Paraguay, and most of them has concerned the redistribution of meat quotas and state support programs in agriculture. Conformity assessment procedures present the concern for other $40 \%$ of respondents.

As regards language and cultural barriers, the biggest challenge for Paraguayan exporters is providing onsite customer service, as indicated by $60 \%$ of respondents. Few companies can afford the 
establishment of a subsidiary in the Russian market. Most companies are inclined to hire intermediaries for this purpose. In any case, there is a problem to find reliable people who would understand the specifics of Paraguayan products and Russian culture at the same time. The loss of the link between exporters in Paraguay and consumers in Russia might undermine the development of ongoing relationships. Not only do language and cultural barriers matter in post-sales stage, they are also of great importance during negotiations. Paraguayan exporters (50\%), like Russian ones (44\%), indicated the inability to use English as medium for negotiations. As a result, misunderstanding in interpretation of customer orders takes place and hinders the development of trade relations, as reported by $40 \%$ of respondents.

Lack of regulatory information makes Paraguayan companies operate in uncertainty, which considerably undermines the prospects of sound cooperation between the countries. The most problematic is the access to information regarding Russian regulations and requirements, mentioned by $70 \%$ of Paraguayan respondents (Figure 11). The situation of burdensome customs procedures is complicated by the lack of information on them (60\%). $40 \%$ of surveyed indicated similar problems to be faced on the Paraguayan side. The same share of Paraguayan respondents experience difficulties in finding business partners, against $56 \%$ of Russian exporters facing this problem. Interestingly, the importance of troubles with identifying sales prospects was reported by the least share of Paraguayan answerers $(30 \%)$ in contrast to Russia, where the largest share (78\%) indicated this challenge. Overall Paraguayan perception of information-related barriers is reverse to the Russian one.

\section{Graph 11: The most important information-related barriers in trade with Russia}

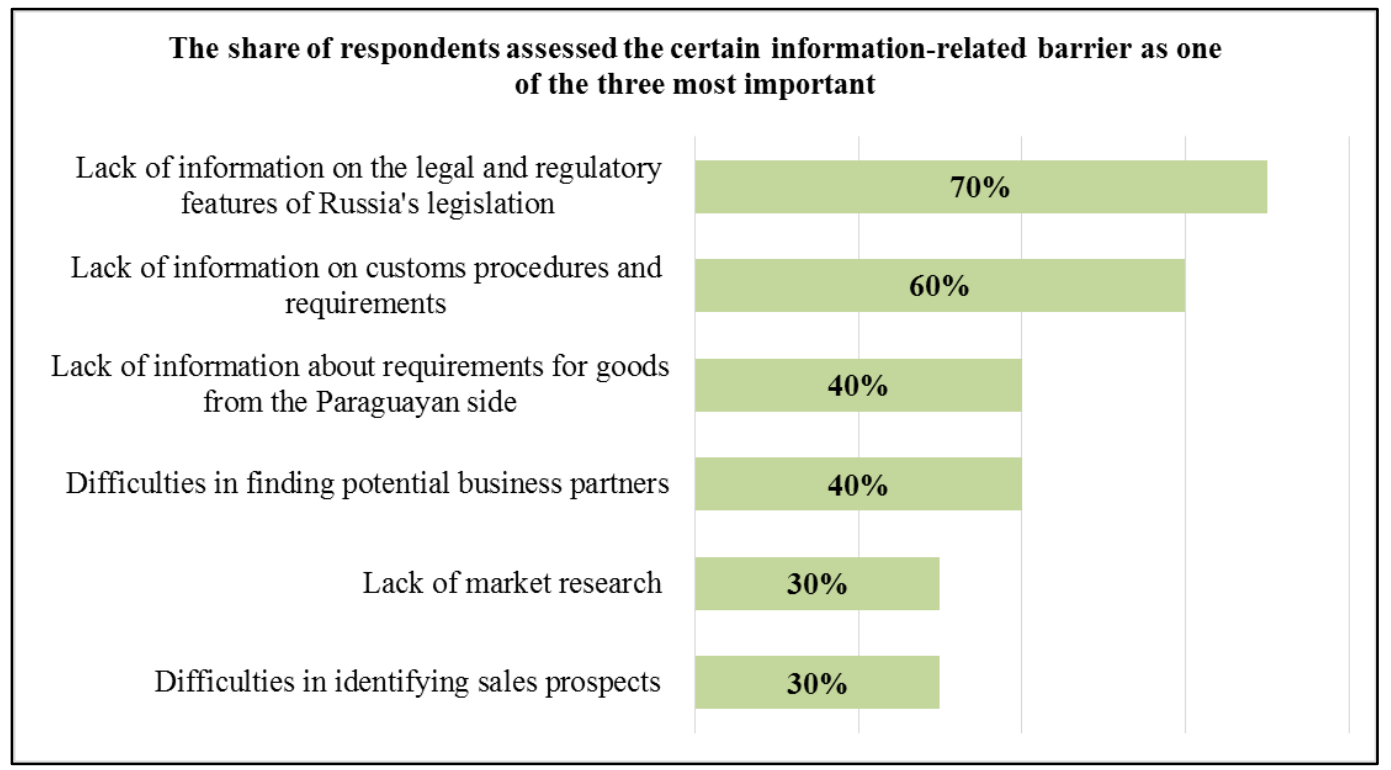

Source: Compiled from questionnaire data

Paraguayan companies face or expect to face similar problems to those of Russian exporters about finding local distributors. A hefty $80 \%$ stated this challenge. In addition, Paraguayan companies expressed concern regarding the image of Paraguayan products. We have not found any research on this issue, which would validate the bad reputation of goods produced in Paraguay in the Russian market. It would be interesting to investigate the genuine attitude of Russian consumers to Paraguayan products and 
origins of such a perception of Paraguay's exporters. A third of respondents also identified the difficulty in entering Russian market owing to the high concentration of its retailers. Yet Paraguayan companies do not predominantly observe the restrictions on either trade intermediaries or post-sales services, indicated only by a single company's representative.

Not the access to trade finance or to government support, but rather the lack of understanding how to deal with them presents the major obstacle for Paraguayan companies. $60 \%$ of them suffer from scarce knowledge and skills needed for handling finance-related issues. The second largest share of respondents, namely $50 \%$, singled out the problem of trade finance unaffordability due to high interest rates or costs of "screening". Yet companies do not attach that much significance to exchange rate fluctuations, in particular when comparing with the response from the Russian side. Only 20\% of Paraguayan respondents concerned this problem against $67 \%$ of the Russian ones.

Furthermore, respondents were asked to define where the highest costs in trade with Russia are concentrated. The majority $(70 \%)$ have indicated that transportation and logistics services, which are transversal to the whole trade chain, generate the major part of total trade costs (Figure 12). This statement is consistent with the Paraguayan companies' perception of such costs being one of the most significant impediments to trade with Russia. Other $20 \%$ stated that customs-related costs generate the largest share of trade costs, which is also in line with our findings on the most important barriers to trade with Russia. The remaining 10\% indicated that the highest trade costs arise on the Russian side.

\section{Graph 12: The location of the highest costs in trade with Russia}

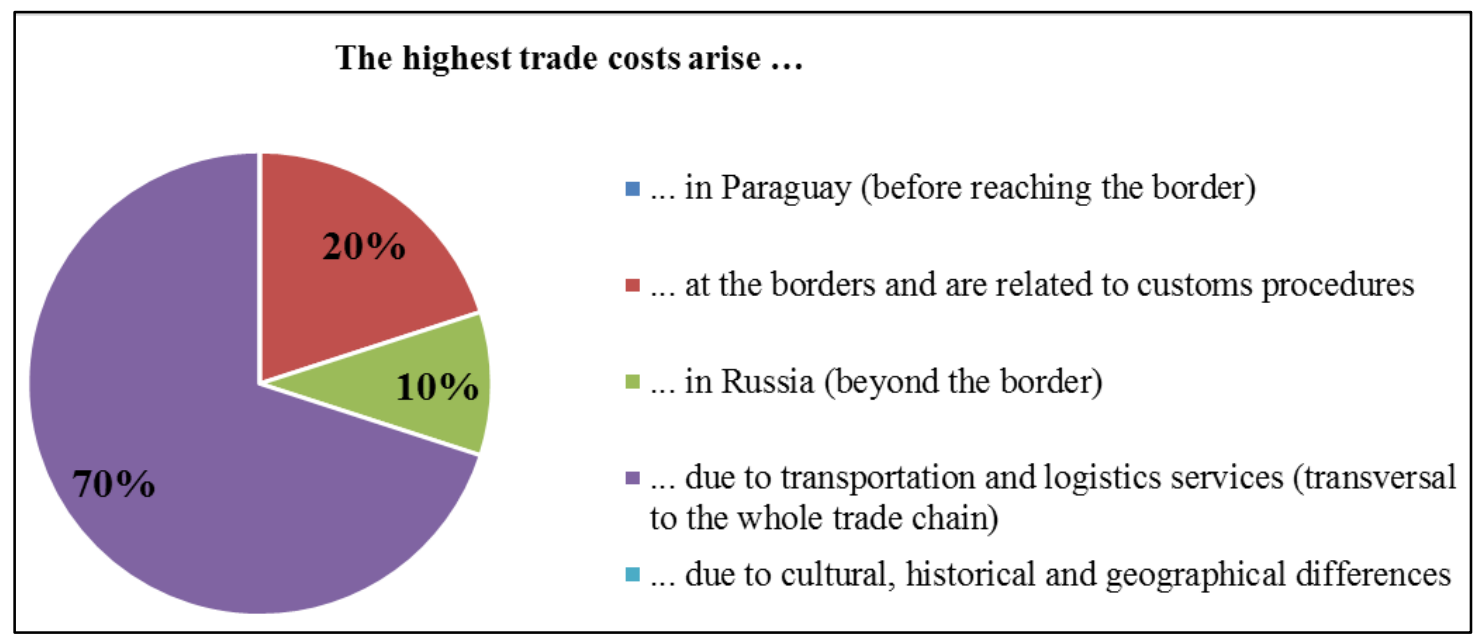

Source: Compiled from questionnaire data

Among the most important barriers considered above, the majority present the hurdles intrinsic only to doing business with Russia, although some are inherent to the overall export activities of Paraguayan companies regardless the destination market. To be more precise, we suppose the following obstacles to be specific for the Paraguay - Russia case: transportation issue, NTMs applied by the Russian government, difficulties with providing onsite service and with finding distributors in the Russian market, and the lack of information about Russian regulations. However, quantitative restrictions imposed by the Paraguayan government to various types of exported goods as well as the insufficient information about customs requirements and the scarce skills required for handling finance -related issues hinder Paraguayan 
export performance in general. These problems rather influence the Paraguayan companies' decision whether to conduct export operations or not. The Russian market indirectly experiences the consequences of such decisions, but these impediments certainly do not serve as a decisive factor in Paraguay's trade with Russia.

\section{Conclusion}

The recent intensification of political dialogue between Russia and Paraguay has been not supported by the increase of bilateral trade, although both states have potentials to encourage their exports. High trade costs could be a reason for the gap between what the countries could export and what they actually export to each other. The survey of Russian and Paraguayan exporters let us infer that trade costs are important for companies' export decisions and consequentially for the development of the Russian-Paraguayan trade relations. For the Paraguayan companies, they serve as a decisive factor when making a decision entering to Russia's market. For the Russian export firms, they also do matter, although an insufficient market capacity sometimes becomes a stumbling block, which makes a trade cost issue relatively less important.

Transportation and logistics costs significantly impede the exports of both countries, although quite expectedly given their remoteness and Paraguay's landlockedness. However, while burdensome and lengthy transportation process indeed represents number one problem for Paraguayan exporters, the top concern for Russian export companies is information-related barriers. Prospective Russian exporters are mainly discouraged by the lack of information about Paraguay's market, in particular information that could let them identify sales prospects and find trustworthy trade partners and distributors. Paraguayan exporters complained about inaccessibility of information about Russian legislation. In addition, insufficient information exchange induces the wrong perception of trade costs, which if being overestimated, can also prevent Russian and Paraguayan companies from entering the markets of each other.

Paraguayan firms also suffer from at-the-border barriers, especially from cumbersome customs procedures and various restrictive measures imposed by the Paraguayan government, which hinder the country's export in general, and SPS measures applied by the Russian government and thus influencing bilateral trade relations. For the Russian exporters, neither customs procedures, nor tariffs and NTBs have been identified as causing much trouble on the way to Paraguay. The Paraguayan exporters also underlined language and cultural barrier as a factor largely complicating the provision of onsite services. These impediments were highlighted as the most important obstacles specific to trade between Russia and Paraguay, although companies certainly experience other difficulties inhibiting their export activities in general and consequentially hampering the Russian-Paraguayan trade.

We should acknowledge that the major costs in trade between the countries are induced by the geographically predetermined conditions. To a larger extent, policy makers are not capable of addressing the high freight rates and the complexity of logistics. However, we believe that this fact does not imply that Russia and Paraguay are doomed to scant trade flows. Some measures could be undertaken to reduce trade costs and thus generate positive effects on trade. 
Russian and Paraguayan policy makers could concentrate their efforts on the improvement of institutional frameworks for a better exchange of information between their countries. There is no unique institutional structure guaranteed to decrease limitations for market opportunities and business development (The World bank, 2002); however, some recommendations could be made taking into account the modern infrastructure for the expansion of the Russian-Paraguayan cooperation. Within currently existing Diplomatic Missions or other institutes aiming at export promotion, it seems practical to establish research departments revealing market opportunities. In addition, associations of exporters could provide "best practices" of entering the Russian and Paraguayan markets, which would help new comers to identify the most feasible way for their entry and to prepare for the possible hurdles to be faced. Companies' participation in exhibitions and fairs organised in Russia and Paraguay is also advisable.

Moreover, trade houses could reduce companies' costs for advancing the products on the markets of each other countries. In order to engage small and medium enterprises in the Russian-Paraguayan trade, the creation of an effective e-commerce platform would be extremely helpful. Difficulties induced by language and cultural differences could be addressed through the educational channels. Russian and Paraguayan universities could have programmes preparing specialists in particular areas, such as economics, law, engineering, medical science, etc. with studying specifics of Latin American countries and Russia respectively as well as their languages.

Further research could be carried out in order to deepen the analysis of costs in trade between Russia and Paraguay. As this paper is more exploratory by nature, the future studies should be more focused on real practices and implementations. First, a case study of particular companies, which are already engaged in exporting or which had attempted to enter the markets of these countries but failed to do so, could be implemented. In addition, the presented empirical research could be improved if a larger sample size of companies to survey would be obtained. Second, a number of interviews with local stakeholders could be conducted. In this sense, stakeholders are represented not only by businessmen or representatives of associations and non-governmental organizations promoting the Russian-Paraguayan commercial cooperation, but also importantly policy makers at different levels. These would contribute to understanding of what policy instruments could be applied to reduce specific trade costs, what policy makers intend to do and how they assess the overall level of solvability of revealed problems. The perspectives from governmental officials could provide more specific recommendations for the development of proper institutional framework. Finally, it would be valuable to conduct a comparative analysis of costs that Russia faces in trade with Paraguay and with other Latin American countries. Even that we may assume that findings could be applied to a certain extent for the Russian-Latin American trade in general, such estimation needs verifications. 


\section{References}

Almeida E., Bastos F., Quijada J. A. \& Acevedo, M. C. (eds.) (2018) Paraguay: rutas para el desarrollo. IDB. Anderson, J. E., \& Van Wincoop, E. (2004). Trade costs. Journal of Economic Literature, XLII, 691-751. Arvis, J-F., Duval, Y., Shepherd, B., Utoktham, C., \& Raj, A. (2016). Trade Costs in the Developing World:1996-2010. World Trade Review, 15(3), 451-474. doi:10.1017/S147474561500052X.

Baldwin, R., \& Harrigan, J. (2011). Zeros, Quality and Space: Trade Theory and Trade Evidence. American Economic Journal: Microeconomics, 3(2), 60-88. doi:10.1257/mic.3.2.60.

Bernard, A. B., Jensen J. B., \& Schott, P. K. (2006). Falling trade costs, heterogeneous firms, and industry dynamics. Journal of Monetary Economics, 53(5), 917-937. doi:org/10.1016/j.jmoneco.2006.05.001.

Blank, S. \& Kim, Y. (2015) Russia and Latin America: The New Frontier for Geopolitics, Arms Sales and Energy. Problems of Post-Communism, Vol. 62, No. 3, 159-73. doi.org/10.1080/10758216.2015.1019817.

Cabral López, M. A. (2018). Paraguay y Rusia: algunas notas sobre su relacionamiento (1992-2016) [Paraguay and Russia: some notes on their relationship (1992-2016)]. ACADEMO (Asuncion), 5(1), 43-52. doi:10.30545/academo.2018.ene-jun.5.

Cruz, J. A. (2015) Strategic Insights: from Ideology to Geopolitics: Russian Interests in Latin America. Current Politics and Economics of Russia, Eastern and Central Europe, Vol. 30 Issue 1-2, 175-185.

Davydov, V.M. (2016). Strategic Partnership in the Context of Russian-Latin American Relations, Herald of the Russian Academy of Sciences, 86 (2), 86-93.

Decreux, Y., \& Spies, J. (2016). Export Potential Assessments: A methodology to identify export opportunities for developing countries. Retrieved June 23, 2018, from http://exportpotential.intracen.org/media/1089/epa-methodology_141216.pdf (accessed April 26, 2018).

Diakantoni, A., Escaith, H., Roberts, M. \& Verbeet, Th. (2017) Accumulating Trade Costs and Competitiveness in Global Value Chains, WTO Working Paper ERSD-2017-02.

Eliseeva, D. S. (2014) Neproizvoditel'nye izderzhki uchastnikov vneshnejekonomicheskoj dejatel'nosti pri sovershenii tamozhennyh operacij [Non-production costs of foreign economic agents performing customs operations], Vestnik Rossijskoj tamoz̧hennoj akademii [Bulletin of the Russian Customs Academy], 4 (29), 172-178.

Federal Customs Service of Russia. (2018). Trade flows between Russia and Paraguay from http://www.customs.ru/

Gladkih, A. (2018, April 09). Kto p'et rossiyskoe pivo za rubezhom [Who drinks Russian beer abroad]. PROVED, pp. Retrieved from http://xn--b1ae2adf4f.xn--p1ai/article/47115-kto-petrossiyskoe-pivo-za-rubezhom-.html.

Global Trade Alert Database. (2018). Retrieved November 28, 2018, from https://www.globaltradealert.org/country/173/affected-jurisdictions_161/periodfrom_20090101/period-to_20191128

Hausmann, R., Klinger, B., \& Wagner, R. (2008). Doing Growth Diagnostics in Practice: A 'Mindbook'. CID Working Papers, 177.

Hoekman, B., \& Nicita, A. (2011). Trade Policy, Trade Costs, and Developing Country Trade. World Development, 39(12), 2069-2079. doi:10.1016/j.worlddev.2011.05.013.

Hummels, D. (1999). Have International Transportation Costs Declined? Chicago, IL: University of Chicago. Hummels, D. (1999). Toward a geography of trade cost. Chicago, IL: University of Chicago Press.

ITC. (2013). Paraguay: Perspectivas Empresariales - Serie del ITC sobre Medidas No Arancelarias [Paraguay: Business Perspectives - ITC Series on Non-Tariff Measures]. Geneva, Switzerland: ITC. 
Valeriia S. Ryzhkova, Alexandra G. Koval

The Role of Trade Costs in the Russian-Paraguayan Trade Relations

Jeifets, V. (2015). Russia is coming back to Latin America: perspectives and obstacles. In Anuario de la Integración Regional de América Latina y el Caribe - América Latina y el Caribe y el nuevo sistema internacional: Miradas desde el Sur coordinado por Andrés Serbin (CRIES, Buenos Aires), Laneydi Martínez. (CEHSEU, La Habana) y Haroldo Ramanzi (pp. 90-112). CRIES.

Kaukin A. S., Pavlov P. N., \& Filicheva E. V. (2015). Modelirovanie prostranstvennogo raspredeleniya rossiyskikh vneshnetorgovikh potokov s uchetom realnikh izderzhek transportirovki [Modeling spatial distribution of Russian foreign trade flows taking into account the actual transportation costs]. Rossiyskoe predprinimatelstvo, 16(23), 4297-4310.

Kaukin, A. S., \& Idrisov G. I. (2013). Analiz izderzhek peremescheniya tovarov pri modelirovanii vneshnetorgovikh potokov [Analysis of costs of moving goods in the modelling of foreign trade flows]. Rossiyskoe Predprinimatelstvo, 12(234), 23-31.

Korchagin, U. V. (2007). Rossiya i Paragvay narashchivayut sotrudnichestvo [Russia and Paraguay increase cooperation]. Mę̧hdunaridnaya ₹̧bizn, 10, 19-25.

Koval, A.G. (2017) Russian Outward Foreign Direct Investments in Latin America: Contemporary Challenges and Prospects. In: Liuhto, K., Sutyrin, S.F., Blanchard, J.F., eds. The Russian Economy and Foreign Direct Investment. London and New York: Routledge, 230-247.

Lopez Arevalo, J. A. (2018). Las relaciones comerciales (intra e interindustriales) de Rusia con América Latina y el Caribe, 2000-2015, Iberoamérica, 2, 68-97.

Martí, L. \& Puertas, R. (2017) The importance of export logistics and trade costs in emerging economies. Maritime Economics \& Logistics, 2(19), 315-333. doi.org/10.1057/mel.2015.31

Mashkova, T. N. (2018) Current directions for the development of cooperation with the countries of Latin America and the Caribbean, Presentation at the Conference 'Export Day: How to export and do business with the countries of Latin America', Saint Petersburg, April 18.

Medvedev, D. (2016). Social and economic development of Russia: Finding new dynamics. Russian Journal of Economics, 2(4), 327-348. doi:org/10.1016/j.ruje.2016.11.001.

Melitz, M. J. (2003). The impact of trade on intra-industry reallocations and aggregate industry productivity. Econometrica, 71(6), 1695-1725.

Ministry of Industry and Trade. (2017, October 25). Rossiya planiruet sozdat' v Paragvae proizvodstvennuyu zony [Russia plans to create a production zone in Paraguay]. Retrieved from Ministry of Industry and Trade of the Russian Federation: http://minpromtorg.gov.ru/presscentre/news/\#!rossiya_planiruet_sozdat_v_paragvae_proizvodstvennuyu_zonu_

Moïsé, E., \& Le Bris, F. (2013). Trade Costs - What Have We Learned?: A Synthesis Report. Paris, France: OECD Publishing. doi.org/10.1787/5k47x2hjfn48-en.

Molchanov, N. N. (2018). Ankyetniy opros [Questionnaire survey]. In N. N. Molchanov (Ed.), Marketing innovatsiy (pp. 123-128). Moscow, Russia: Izdatelstvo Urait.

Muendler, M. A. (2004). Trade, technology, and productivity: A study of Brazilian manufacturers, 19861998. CESifo Working Paper Series, 1148.

Novy, D. (2013). Gravity redux: measuring international trade costs with panel data. Economic Inquiry, 51(1), 101-121. doi.org/10.1111/j.1465-7295.2011.00439.x.

OECD. (2017). Trade Facilitation Indicators Database, Retrieved November 28, 2018, from http://compareyourcountry.org/trade-facilitation

OECD/WTO. (2015). Why Trade Costs Matter for Inclusive, Sustainable Growth. Paris, France: OECD Publishing. doi:org/10.1787/aid_glance-2015-en.

Paniev, Y. (2013). Cooperacion Economico-Comercial Ruso-Latinoamericana: Adelantos y Deficiencias. Iberoamérica, No. 3, 111-127. 
Pavlova, E. (2017). A Russian Challenge to Multipolarity? The Prospects for Political Cooperation between Russia and Latin America. Problems of Post-Communism, Vol. 64, 1-15.

REC. (n.d.). Renking perspektivnosti stran dlya eksporta [Rating of countries' prospects for exports]. Retrieved June 23, 2018, from Russian Export https://www.exportcenter.ru/international_markets/country_rating/

REDIEX. (2015, August). Análisis del Potencial de Exportación Paraguay-Federación de Rusia [Analysis of the export potential Paraguay-the Russian Federation]. Retrieved June 24, 2018, from REDIEX: http://www.rediex.gov.py/wp-content/uploads/2017/01/Rusia_Potencial_Export.pdf

RIA Novosti. (2018). Rossija i Paragvaj gotovjat soglashenie o strategicheskom al'janse [Russia and Paraguay prepare the agreement of strategic alliance]. Retrieved November 28, 2018, from https://ria.ru/politics/20180615/1522817084.html

Sopilko, N. Y., Navrotskaia, N. A., Kovaleva E. A., Orlova, A. F. \& Grigoryeva, A. V. (2017). Dynamics factors and slow-response characteristics of Russian trade ties. Journal of Advanced Research in Law and Economics, 2(24), 625 - 634.

Tavdumadze, N. K. (2017). K 25-letiju vosstanovlenija dipotnoshenij mezhdu Rossiej i Paragvaem [To the 25th anniversary of the restoration of diplomatic relations between Russia and Paraguay]. Mezhdunarodnaja zhizn', 5, 67-82.

The Analytical Center for the Government of the Russian Federation, \& the Russian Export Centre. (2016). Strategicheskaya sessiya: Baryeri $i$ vozmozhnosti razvitiya mezhdunarodnoy koopyeratsii $i$ eksporta [Strategic session: Barriers and opportunities for the development of international cooperation and export]. Retrieved from http://ac.gov.ru/files/content/10050/otchet-stratsessiya-09-09-pdf.pdf.

UNESCAP/World Bank. (n.d.). Trade Costs Database. Retrieved June 26, 2018, from http://www.unescap.org/resources/escap-world-bank-trade-cost-database

World bank. (2018). Doing Business: Trading across Borders, Retrieved November 28, 2018, from http://www.doingbusiness.org/en/data/exploretopics/trading-across-borders

World bank. (2002). World Development Report: Building Institutions for Markets. Oxford: Oxford University Press.

WTO. (2008). World Trade Report 2008: Trade in a globalizing world. Geneva, Switzerland: WTO.

Yakovlev, P. (2017) Rossija - Latinskaja Amerika: strategija proryva na rynki nesyr'evoj produkcii [RussiaLatin America: a breakthrough strategy for non-primary products markets], Latinskaja Amerika, $12,15-28$.

Yakovlev, P. (2015). Rossiya i Latinskaya America na fone zapadnih sanktsiy [Russia and Latin America against the background of Western sanctions]. E-journal Perspectives and Prospects, 2, 82-97. Retrieved from http://journal.perspektivy.info/. 